\title{
FROM THE BIG APPLE TO BIG BEN: INTERNATIONAL GUIDANCE FOR ABU DHABI'S MODERN HERITAGE PRESERVATION INITIATIVE
}

\begin{abstract}
Sarah P. Harrell*
"We shape our buildings; and afterwards our buildings shape us." Winston Churchill ${ }^{1}$

\section{INTRODUCTION}

Preserving our "built environment" enriches our lives with history. Many great cities of the world formed over hundreds, or even thousands, of years; their skylines are a majestic mix of new and old. These cities have struck a balance between development and preservation through the use of laws and policies. But how does a city with relatively little "history" form a meaningful built environment for its people?

This Note starts by highlighting the unique issue of architectural preservation in Abu Dhabi, a city whose built environment is remarkably modern. Competing views of modernization and preservation are pulling this particular city in opposite directions. ${ }^{2}$ In 2011 , in an effort to protect Abu Dhabi's modern heritage, a cultural organization launched the Modern Heritage Preservation Initiative, aimed at developing strategies for managing preservation in the midst of urban renewal. ${ }^{3}$ As of the writing of this Note, surveys, record gathering, and other assessments are still in process, but this Note discusses the goals of the initiative and the rationales behind it.

Next, this Note discusses theories of why the law should help protect historically significant architecture in cities - both in general and in Abu Dhabi specifically. This portion includes an explanation of the "built environment" and why it merits protection and regulation. This Note then discusses how the goals of urban development and modernization compete
\end{abstract}

* Sarah P. Harrell is a 2014 J.D. graduate of Indiana University Robert H. McKinney School of Law.

1. Winston Churchill, Speech to the House of Commons (Oct. 28, 1943), in Famous Quotations and Stories, ChurChill Centre AND Museum, http://www.winstonchurchill.org/ learn/speeches/quotations (last visited Aug. 21, 2014, archived at http://perma.cc/UD3RTGYM).

2. See generally John Henzell, In a Growing City Like Abu Dhabi, What Makes a Building Worth Keeping?, NATIONAL (Aug. 4, 2012), http:/www.thenational.ae/news/uaenews/heritage/in-a-growing-city-like-abu-dhabi-what-makes-a-building-worth-keeping, archived at http://perma.cc/K7V7-9C9G; Amel Chabbi \& Hossam M. Mahdy, Virtuous Circle or Viscious Cycle?: Modern Heritage and Development in Abu Dhabi, 17 INT'L Council on Monuments \& Sites Gen. Assembly 75 (2011).

3. Chabbi \& Mahdy, supra note 2 . 
with the goals of preservation and how and why these goals may be reconciled.

In an effort to find guidance for the future of Abu Dhabi, the next section of this Note describes the legal protection of architecture in two cities famous for their historical landmarks: New York City and London. This Note provides an overview of the legal protections provided by the New York City Landmarks Preservation Act and the United Kingdom's Planning (Listed Buildings and Conservation Areas) Act. This section also explains the functions of related commissions and other regulations.

Finally, this Note analyzes the potential application of the aforementioned laws to Abu Dhabi and suggests different aspects of those laws that would be beneficial to achieve the goals of Abu Dhabi's Modern Heritage Preservation Initiative. Some aspects of the laws in New York City and the United Kingdom could serve as models for Abu Dhabi, while others either would be inappropriate or would require adaptation.

\section{A MODERn CONTROVERSY IN ARCHITECTURAL PRESERVATION: ABU DHABI, UNITED ARAB EMIRATES}

Abu Dhabi's transformation over the past few decades is remarkable. The city's unique history makes for a particularly interesting discussion of architectural preservation. On the one hand, developers and others are focused on making the city continuously bigger and better, tearing down and replacing buildings along the way. ${ }^{4}$ On the other hand, cultural heritage proponents insist that some buildings are worth preserving, even if they are not especially old or historical. ${ }^{5}$ Through a new initiative, the emirate ${ }^{6}$ is working to resolve these seemingly conflicting views. ${ }^{7}$

\section{A. Abu Dhabi's History}

Abu Dhabi is the capital of and most populous city in the United Arab Emirates. ${ }^{8}$ The city experienced a "rebirth" in the 1960 s thanks to an oil boom, ${ }^{9}$ and it developed rapidly from a small settlement into a major city. ${ }^{10}$

4. See infra notes 22-23 and accompanying text.

5. See infra notes 24-26 and accompanying text.

6. An emirate is an Islamic state or jurisdiction that is ruled by an emir. See MERRIAMWebster Dictionary 378 (10th ed. 1994). The United Arab Emirates includes seven emirates: Abu Dhabi, Dubai, Sharjah, Ajman, Umm al-Qaiwain, Ras al-Khaimah, and Fujairah. United Arab Emirates, EMIRATES.ORG, http://www.emirates.org/ (last visited Nov. 26, 2013, archived at http://perma.cc/T8JR-5PFP). The federation lies on the southeastern tip of the Arabian Peninsula. Id.

7. See infra Part II.C.

8. Abu Dhabi, EMIRATES.ORG, http://emirates.org/abudhabi.html (last visited Nov. 26, 2013, archived at $\mathrm{http}: / /$ perma.cc/DH3U-45A6).

9. See, e.g., Henzell, supra note 2; Chabbi \& Mahdy, supra note 2, at 76. 
In the late 1960s when Abu Dhabi's population was only 40,000, Sheikh Zayed commissioned a city planner to design the new Abu Dhabi. ${ }^{11}$ Less than forty years later, the population had already grown past the 600,000 that the plan accommodated, so a new city planner redesigned the city to hold up to 3,000,000 people. $^{12}$

When it comes to built environment, “Abu Dhabi's situation is unique because . . . the entire city - with the lone exception of [one building] dates from the modern era." 13 Even the majority of those buildings built during the rebirth period have been torn down and replaced, often because they had been hastily built to accommodate for rapid growth and were of "mediocre quality."14

Building renewal in Abu Dhabi is also due to changes in planning bylaws that have allowed for increasingly higher-rise buildings. ${ }^{15}$ The rules for permissible building heights were updated frequently, as developers suddenly found shorter structures less economically attractive. ${ }^{16}$ The constant replacement of buildings has become commonplace, so demolition threatens many buildings before their style has the opportunity to become classic. $^{17}$

This change came about to satisfy the increasing demand for apartments and offices and the desire to utilize the limited amount of land in a denser way. This was coupled with the wish to give Abu Dhabi an increasingly modern image and with the availability of funds, which the Government wished to pump into the construction sector to keep this vital economic sector rolling. ${ }^{18}$

Expatriate designers and builders have largely been responsible for Abu Dhabi's aggressive development. ${ }^{19}$ These foreigners, who make up the majority of the emirate's population, tend to come in waves, so they have less knowledge of and appreciation for Abu Dhabi's architectural history. ${ }^{20}$

10. See, e.g., Salma Samar Damluji, Architecture of the United Arab Emirates 101 (Salma Samar Damluji ed., 2006); Chabbi \& Mahdy, supra note 2.

11. Henzell, supra note 2; Chabbi \& Mahdy, supra note 2, at 77.

12. Henzell, supra note 2.

13. Henzell, supra note 2.

14. Damluj, supra note 10, at 117; see also Chabbi \& Mahdy, supra note 2, at 77 (explaining that buildings erected in the 1970s were often of inferior quality because demand was high and there were not enough quality control mechanisms in place).

15. DAmLuji, supra note 10, at 117; Chabbi \& Mahdy, supra note 2, at 78.

16. Chabbi \& Mahdy, supra note 2, at 78.

17. Chabbi \& Mahdy, supra note 2, at 78 .

18. DAmLuJi, supra note 10 , at 117.

19. Chabbi \& Mahdy, supra note 2, at 77.

20. See Chabbi \& Mahdy, supra note 2, at 77 ("This exceptionally big percentage of foreigners and the fast cycles of their turnover have threatened the collective memory of the 


\section{B. The Modern Architecture Preservation Conflict in Abu Dhabi}

Modern buildings in Abu Dhabi face dangers of "unsuitable intervention such as modifications and renovations, lack of awareness and appreciation, damage and real estate bidding." ${ }^{21}$ Developers in Abu Dhabi have a passion for the new, and they have the money to destroy relatively recently constructed buildings and start from scratch. ${ }^{22}$ Thus, Abu Dhabi is caught in a permanent state of change and development. ${ }^{23}$

Meanwhile, cultural heritage activists in Abu Dhabi believe many modern buildings in the city "capture a moment in time" and should be "saved from demolition and restored to their former glory." 24 They consider buildings erected during the 1960 s to be "testimonies to the features of the development and success of the emirate." ${ }^{25}$ The rationale for preserving buildings from each of Abu Dhabi's stages is that it will create a meaningful architectural record of the city's modern evolution. ${ }^{26}$

The cultural heritage activists' goals are not without opposition, of course. According to the Abu Dhabi Authority for Culture and Heritage $(\mathrm{ADACH})$, "[1]ack of awareness and appreciation [is] one of the threats faced by Abu Dhabi's unique post-oil architectural heritage."27 In addition, "[u]nlike archaeological and historical buildings, the modern heritage faces an additional threat represented in the usual demand for modernisation in order to keep up with the latest, cleanest and smartest designs and tastes." 28 Another problem is that most of the professional class in Abu Dhabi only lives in the city for a few years, so they do not have the same connection to the city's past or a "vested interest" in its future. ${ }^{29}$

One example of "a conflict that will occur again and again in Abu Dhabi" is the controversy over a bus station. ${ }^{30}$ It was built in the 1980s and already seems "quaintly old fashioned" compared to the more modern skyscrapers surrounding it. ${ }^{31}$ The Department of Transport wants "to entice drivers to switch to public transport by offering modern and comfortable

emirate.").

21. Press Release, Abu Dhabi Authority for Culture and Heritage Launches Initiative for Preserving Abu Dhabi's Post-Oil Heritage (Aug. 7, 2011), archived at http://perma.cc/KBU8-S5MC.

22. Henzell, supra note 2; see also Press Release, supra note 21.

23. See Press Release, supra note 21.

24. Henzell, supra note 2 (quoting Deborah Bentley, a member of the Royal Institute of British Architects who is based in Abu Dhabi).

25. Press Release, supra note 21.

26. Henzell, supra note 2.

27. Henzell, supra note 2.

28. Henzell, supra note 2; see also Press Release, supra note 21.

29. Henzell, supra note 2 .

30. Henzell, supra note 2; see also Press Release, supra note 21.

31. Henzell, supra note 2. 
facilities." ${ }^{, 32}$ Still, the bus station is well known in the city for its mint green color and "sweeping concrete curves that are the key to its passive solar design." 33 According to one architectural expert, the bus station is environmentally sound and with some minor changes could easily be enjoyed by future generations. ${ }^{34}$

Two clear philosophies have emerged with regard to Abu Dhabi's architectural future: modernization and preservation. These two conflicting goals are what some call "the vicious cycles of Abu Dhabi's urban renewal." ${ }^{35}$ With the proper legal mechanisms, however, these two philosophies could perhaps be reconciled.

\section{Current Modern Heritage Preservation Efforts in Abu Dhabi}

In 2011, ADACH launched its so-called Modern Heritage Preservation Initiative. ${ }^{36}$

"The goal of the initiative is to develop strategies, policies and economic incentives that will ensure that these [modern heritage] resources are protected and appreciated for their inherent merit while seen as boosters in the competitive real estate market, and valued as assets in Abu Dhabi's growing cultural portfolio." 37 The initiative is in its study phase, in which $\mathrm{ADACH}$ is doing surveys, block by block, assessing buildings for their "age, condition, use, and threat [level] ...."38 $\mathrm{ADACH}$ is also gathering various records and conducting case studies. ${ }^{39}$

ADACH recognizes that several elements of change must coincide in order to successfully save Abu Dhabi's modern architectural history. ${ }^{40}$ First, in the cultural context, the public's understanding of heritage must recognize and include modern architecture. ${ }^{41}$ To achieve this end, ADACH will use its surveys and studies to understand and define the aesthetic vocabulary of modern architecture in Abu Dhabi. ${ }^{42}$ Second, in the social context, people need to view living and working in modern heritage

32. Henzell, supra note 2.

33. Henzell, supra note 2.

34. Henzell, supra note 2 (quoting Deborah Bentley).

35. Henzell, supra note 2 (quoting Amel Chabbi and Hossam Mahdy of the Abu Dhabi Authority for Culture and Heritage).

36. Chabbi \& Mahdy, supra note 2, at 75.

37. Chabbi \& Mahdy, supra note 2, at 81 ; see also Press Release, supra note 21 (explaining that the initiative aims to understand and protect modern architectural heritage, which is "a precious contribution to the growing cultural dossier of Abu Dhabi").

38. Chabbi \& Mahdy, supra note 2, at 81. "Threat level" refers to the extent of the possibility the building may be demolished. See Chabbi \& Mahdy, supra note 2, at 81.

39. Chabbi \& Mahdy, supra note 2, at 81.

40. See generally Chabbi \& Mahdy, supra note 2.

41. Chabbi \& Mahdy, supra note 2, at 82.

42. Chabbi \& Mahdy, supra note 2, at 82 . 
buildings as attractive and desirable. ${ }^{43}$ Third, in a technical and economic context, owners and users of modern heritage buildings need assistance and incentives to maintain or refurbish those buildings rather than to replace them. ${ }^{44}$ Fourth, in the political context, different governmental agencies need to work together to create new plans for development and to enforce owners' duties to maintain their buildings. ${ }^{45}$ Fifth, in the legal context, regulations are needed to establish what protections shall be granted to significant buildings, and mechanisms need to be in place to approve alterations and demolitions. ${ }^{46}$

Currently in Abu Dhabi, federal law requires developers to apply for a preliminary cultural resource survey, which ADACH carries out. ${ }^{47}$ Before the launch of the Initiative, ADACH's focus had been on impacts only to paleontological, archaeological, and pre-oil historic resources; now, however, $\mathrm{ADACH}$ is "testing out the waters for preservation" of modern heritage as well. ${ }^{48}$

During its relatively short history, Abu Dhabi has experienced enormous growth and renewal on top of renewal. Those who wish to preserve examples of Abu Dhabi's stages of growth face challenges of apathy, resident turnover, and demand for modernization. The 2011 Initiative shows ADACH's firm commitment to enacting legislation aimed at reconciling these conflicting views. The preservationist goals of $\mathrm{ADACH}$ and others are certainly not unique. As is discussed in the following section, there are many reasons to protect architectural history. With some work, Abu Dhabi can change its laws to reflect preservationist values.

\section{THEORIES OF PRESERVATION AND PROTECTION OF URBAN ARCHITECTURAL HISTORY}

\section{A. Values Associated with Architectural Preservation}

One can frame a discussion of the values associated with architectural preservation in terms of the "built environment." A rather clinical definition of "built environment" is " $[\mathrm{t}]$ he buildings, roads, utilities, homes, fixtures, parks and all other man-made entities that form the physical characteristics of a community." 49 Abu Dhabi's built environment can be seen as

43. Chabbi \& Mahdy, supra note 2, at 82 .

44. Chabbi \& Mahdy, supra note 2, at 82.

45. Chabbi \& Mahdy, supra note 2, at 82.

46. Chabbi \& Mahdy, supra note 2, at 82 .

47. Chabbi \& Mahdy, supra note 2, at 82 .

48. Chabbi \& Mahdy, supra note 2, at 82.

49. Healthy Places Terminology, Centers for Disease Control and Prevention, http://www.cdc.gov/healthyplaces/terminology.htm (last updated Aug. 14, 2013, archived at http://perma.cc/AHM2-29X3). 
consisting of two parts: commercial/residential buildings and larger office buildings for corporations. ${ }^{50}$ The former is marked by experimental and fashionable architectural styles, as well as traditional Arab-Islamic features which embody an effort to create a local identity. ${ }^{51}$ "These features also reflected [plot owners'] taste[s] in architectural style which in most cases represented a simplistic understanding of heritage, modernity, regionalism and internationalism." ${ }^{.52}$ The buildings in the latter category "have a distinctly higher architectural quality" because they were built on bigger plots and were designed by expensive architectural firms. ${ }^{53}$

But the importance of the "built environment" involves more than just the buildings themselves. Professor John Nivala of Widener University Law School calls the "built environment" "a richly representative setting which infuses our lives with an identity and a sense of continuity essential to our well-being." 54 The "built environment" has cultural values: "The structures [of a built environment] provide a physical framework for daily use and an associational framework connecting us to the history, ideology and civic systems of our culture." 55 In Abu Dhabi, as mentioned in Section II.C. above, the cultural importance of architecture is one of the driving forces behind the Modern Heritage Preservation Initiative. ${ }^{56}$ Protecting important buildings in Abu Dhabi will "provide benchmarks" of the city's "physical and cultural transformation." 57

In addition to cultural values, preservation of architecture is motivated by the goals of inspiration and aesthetics. Such goals are evident in the purposes behind preservation laws in some of the most historically significant areas of the world. One of the purposes of the New York City Landmarks Preservation $\mathrm{Act}^{58}$ is to "foster civic pride in the beauty and noble accomplishments of the past ...."59 The purpose of English Heritage $^{60}$ is "to make sure the best of the past is kept to enrich our lives today and in the future." ${ }^{1}$ The legal mechanisms for architectural preservation in New York City and England both seem to be at least partially motivated by the intangible values that architecture imparts on

50. See DAmLuj, supra note 10 , at 111 .

51. See Damluji, supra note 10, at 112-13; Chabbi \& Mahdy, supra note 2, at 77.

52. DAMLUJI, supra note 10, at 113.

53. DAMLUJI, supra note 10, at 116.

54. John Nivala, Saving the Spirit of Our Places: A View on Our Built Environment, 15 UCLA J. ENVTL. L. \& POL'Y 1, 5 (1997).

55. Id. at 11 .

56. See supra note 37 and accompanying text.

57. Chabbi \& Mahdy, supra note 2, at 81 .

58. See infra Part IV.A.1.

59. N.Y.C., N.Y., AdmIN. CodE § 25-301(a) (2012).

60. English Heritage is discussed infra Part B.1.

61. What We Do, ENGLish HeritAGE, http://www.english-heritage.org.uk/ about/interactive/ (last visited Aug. 22, 2014, archived at http://perma.cc/XA55-XB4H). 
society. "A landmark . . . help[s] foster community cohesion. A frequent rationale for landmark designation is the building's association with past events or notable persons; its physical presence can unite the community by reminding members of a common past.",62

Community building is another value behind ADACH's Initiative. One of the future goals for planning in the emirate is "to celebrate the individuality of neighborhoods, districts, and cities by understanding the history of their development and integrating these findings with future expansion plans." ${ }^{~}{ }^{3}$ In Abu Dhabi, most of the buildings now standing were built within the lifetimes of current and recent generations. ${ }^{64}$ Those buildings, therefore, give the people of the city a sense of place. ${ }^{65}$ Landmark status for Abu Dhabi buildings like the bus station, among others, would potentially serve the community, reminding residents of the city's unique history, even those residents who are not natives of the city or even the country. ${ }^{66}$

Finally, architectural preservation also serves the economic functions of real estate marketability and tourism. One of the stated purposes of the New York City Landmarks Preservation Act is to "stabilize and improve property values in [historically and aesthetically important] districts." Numerous studies across the United States suggest that landmark designation increases property values and makes neighborhoods attractive to buyers and developers. ${ }^{68} \mathrm{~A}$ special historical designation sets a building or district apart from others, and many buyers are drawn to the "unique qualities and ambiance of a historic property." ${ }^{, 69}$

Abu Dhabi's real estate market is already on the upswing due to various government projects, the merger of two major developers, and job

62. Carol M. Rose, Preservation and Community: New Directions in the Law of Historic Preservation, 33 StAn. L. ReV. 473, 497 (1981).

63. Chabbi \& Mahdy, supra note 2, at 82.

64. See Henzell, supra note 2.

65. Chabbi \& Mahdy, supra note 2, at 81.

66. A significant portion of Abu Dhabi residents are not from the city and do not live there long. See Chabbi \& Mahdy, supra note 2, at 77.

67. N.Y.C., N.Y., ADMIN. CoDE $§ 25-301$ (a) (2013).

68. See Rebecca Birmingham, Smash or Save: The New York City Landmarks Preservation Act and New Challenges to Historic Preservation, 19 J.L. \& POL'Y 271, 283 (2010); Ken Bernstein, The Top Ten Myths About Historic Preservation 1, archived at http://perma.cc/R8H3-QYAJ; Preservation Ordinance FAQ, NAT'L TRUST FOR HISTORIC PRES., http://www.preservationnation.org/information-center/law-and-policy/legal-resources/ preservation-law-101/local-law/ordinances.html\#.UkyCxT-mWjI (last visited Nov. 3, 2013, archived at http://perma.cc/83MH-HAKW) ("In addition to instilling pride within a community, historic preservation laws have been helpful in spurring tourism, generating new investment in otherwise forgotten areas, and increasing local tax revenue and property values.").

69. Bernstein, supra note 68. 
growth. ${ }^{70}$ However, "[a]gents remain skeptical that the new initiatives alone will be enough to lead to a full recovery for Abu Dhabi property."71 As developers build more affordable housing options, the presence of designated landmarks or neighborhoods might help distinguish certain properties from the rest and make them more valuable and attractive.

Preservation of architecture in urban areas is of interest not only to residents, but also to visitors. New York City legislators recognized their city's position as a tourism capital, stating in the Landmarks Preservation Act "that the standing of this city as a world wide tourist center and world capital of business, culture and government cannot be maintained or enhanced by disregarding the historical and architectural heritage of the city and by countenancing the destruction of such cultural assets."

In 2012, Abu Dhabi's tourism market was "subdued" and was expected to remain that way in $2013 .^{73}$ Currently, some of the emirate's biggest tourism draws are Ferrari World, camel racing, and shopping malls. ${ }^{74}$ If Abu Dhabi could put more emphasis and value on its built environment, it could build a reputation as a unique tourist destination for architecture lovers. A growth in tourism would likely lead to a growth in retail spending as well. ${ }^{75}$

A city's built environment helps define its identity. That identity includes culture, community, and economy. Cities like New York and London have long recognized the importance of assigning value to the built environment. As Abu Dhabi grows, so too does the need for its government and its people to recognize their city's unique architectural history and the benefits that history gives them.

\section{B. The Necessity of Legal Protection for Architectural Heritage}

Because preservation of architecture serves many culturally, historically, and economically valuable purposes, it is important for a city's or country's laws to reflect a public policy recognizing those purposes. The

70. Lucy Barnard, Abu Dhabi's Property Market to Shine by 2015, National (Jan. 16, 2013), http://www.thenational.ae/business/industry-insights/property/abu-dhabis-propertymarket-to-shine-by-2015, archived at http://perma.cc/FWP4-WFJA.

71. Id.

72. ADMIN. § 25-301(a).

73. Andy Sambidge, Abu Dhabi Retail, Tourism Seen Subdued in 2013, ARABIANBUSINESS.COM (Dec. 22, 2012, 9:47 AM), http://www.arabianbusiness.com/abudhabi-retail-tourism-seen-subdued-in-2013-483588.html, archived at http://perma.cc/34HJW322.

74. These are some of the things listed under "Most visited" on Abu Dhabi's main tourism website. VISIT ABU DHABI, http://visitabudhabi.ae (last visited Jan. 19, 2013, archived at http://perma.cc/WRQ6-URRA).

75. See Sambidge, supra note 73 (noting that in the emirate of Dubai, an increased number of tourists in 2012 had benefited its retail market). 
US federal government, states, municipalities, and foreign nations all share the belief that historical preservation laws are necessary, and all have various laws regulating the preservation of architecture. ${ }^{76}$ These legislative measures - at least in the United States - represent the recognition of two different concerns: first, that many structures have been and continue to be destroyed without prior consideration for their historical importance or the potential to successfully preserve them; and second, that certain architectural treasures are beneficial to the general public's quality of life. ${ }^{77}$ Regulations are therefore needed "to protect the public's interest in their heritage," as private owners and private property rights are not enough to internalize and capture the full cultural and historical value of architectural preservation. $^{78}$

Some experts point to the downfalls of historical preservation laws. One argument is that they restrict new construction of affordable housing and therefore make cities more expensive and effectively exclude anyone who is not wealthy. ${ }^{79}$ However, one could just as easily argue that while progress and affordable housing are desirable, loss of cultural values in a city is just as regrettable as some loss of affordability.

Another argument is that preservation laws create a fear of modernism to the point that they do a disservice to an area's architectural development. ${ }^{80}$ After all, "the city that contains not enough new buildings is as robbed of the reality of time as the one that contains not enough old ones." ${ }^{\prime 81}$ This argument was once answered by New York City's Deputy Mayor for Planning, who said the landmarks process is meant not only to preserve the past, but also to foster creativity for present architects to create

76. Various US federal laws promulgated over the years have regulated government actions and facilitated the keeping of landmark registers. See generally Marilyn Phelan, A Synopsis of the Laws Protecting Our Cultural Heritage, 29 NEw ENG. L. REV. 63 (1993). In addition, all fifty US states have their own Historic Preservation Offices that assist the federal government, and many states carry out their own preservation programs. Understanding Preservation Law, NAT'L TRUST FOR HISTORIC PRES., http://www.preservationnation.org/information-center/law-andpolicy/legal-resources/\#.UkyLVz-mWjI (last visited Nov. 3, 2013, archived at http://perma.cc/FH54-VVSE). Even smaller, local preservation ordinances create boards that may designate local landmarks. Id.

77. See Penn Cent. Transp. Co. v. City of N.Y., 438 U.S. 104, 107-08 (1978).

78. J. Peter Byrne, Historic Preservation and Its Cultured Despisers: Reflections on the Contemporary Role of Preservation Law in Urban Development, 19 GEO. MASON L. REV. 665, 675 (2012) ("Regulation may be done well or poorly, but regulation must exist.").

79. See, e.g., Edward L. Glaeser, Triumph of the City: How Our Greatest InVENTION MaKes Us Richer, SMARTER, Greener, HEAlthier, AND HaPPier (2011). Even Glaeser admits that "there is much worth keeping in our cities," but says that preservation "always comes at a cost." Id. For a critique of Glaeser's book, see generally Byrne, supra note 78 .

80. See, e.g., Paul Goldberger, Architecture View; A Commission that has Itself Become a Landmark, N.Y. TiMES (Apr. 15, 1990), archived at http://perma.cc/Z3YJ-ELL4.

81. Id. 
buildings that will become landmarks in the future. ${ }^{82}$ Professor Carol Rose mentions in an article that "it is arguable that restrictions on landmark alteration might encourage builders, knowing that their investment may be preserved indefinitely, to strive for creative excellence." ${ }^{83}$ Rose seems to suggest that this incentive rarely exists in reality. ${ }^{84}$ However, it could be a relevant consideration to builders in Abu Dhabi, where many poor quality buildings have had a short life. A legal reassurance that important and high quality structures are valued could help replace the old "demolish and replace" mindset that has been the norm during Abu Dhabi's development.

Ultimately, "[p]reservation and progress can be mutually sustaining. The challenge is to come up with legal standards and procedures that advance the individual and cultural benefits of preservation . . . without stifling the city's necessary growth." ${ }^{\circ 5}$ In Abu Dhabi, this means protecting cultural icons like the bus station from demolition, but recognizing when they are due for improvements or when they no longer hold value to the community.

\section{THE EFFECTIVENESS OF ESTABLISHED ARCHITECTURAL PRESERVATION PROGRAMS IN NEW YORK CITY AND LONDON}

This Note uses the preservation laws of New York City and London as guidance for Abu Dhabi as it works toward a successful preservation regime. New York City and London are used as examples because they represent two urban areas in different parts of the world, and both are popular tourist destinations famous for their landmarks. ${ }^{86}$ Both cities' preservation laws have been in place for decades. New York City has its

82. Id.

83. Rose, supra note 62, at 501.

84. Rose, supra note 62 , at 502 ("To be sure, this argument would be far more persuasive if there were no private law devices (such as easements and covenants) by which the original builder could attain the same protection. I raise it only to suggest the ambiguity of incentives for the original builder to invest in creative and dramatic construction.").

85. Nivala, supra note 54 , at 41 .

86. In 2011, there were 50.9 million visitors to New York City. NYC Statistics, NYCGO.COM, http://www.nycgo.com/articles/nyc-statistics-page (last visited Nov. 3, 2013, archived at http://perma.cc/5BF6-2N48). London saw 15.5 million visitors in 2012. Inbound Tourism Facts, VISITBRITAIN.ORG, http://www.visitbritain.org/insightsandstatistics/ inboundtourismfacts/index.aspx (last updated Apr. 2013, archived at http://perma.cc/SF6NKEG). Famous New York City designated landmarks include the Chrysler Building, the Empire State Building, and the main building at Ellis Island. See BARBARALEE Diamonstein-Spielvogel, The Landmarks of New York: An Illustrated Record of THE CitY's Historic BuILDINGs (2011). London's listed buildings include Westminster Abbey and the British Museum. See Grade I Listed Buildings in Greater London, England, BRITISH LISTED BUILDINGS, http://www.britishlistedbuildings.co.uk/england/greater+ london/I (last visited Nov. 6, 2013, archived at http://perma.cc/R2BA-CT8T). 
own local legislation, ${ }^{87}$ while London follows a U.K.-wide act. ${ }^{88}$ Some aspects of the two acts are similar, and for the purposes of this Note, portions of one act that overlap with the other are not discussed in great detail. Some less relevant provisions of both acts are not mentioned.

\section{A. The New York City Landmarks Preservation Act}

\section{Overview of the Act and Related Authority}

Mayor Robert Wagner signed the New York City Landmarks Preservation Act (hereinafter "NYC Act") into law in 1965 after it was found that many historically or aesthetically important buildings in the city had been destroyed even though their preservation was both possible and desirable. ${ }^{89}$ The NYC Act declared that it was public policy to protect, enhance, and perpetuate use of such buildings "in the interest of the health, prosperity, safety and welfare of the people." 90

The NYC Act created the Landmarks Preservation Commission. ${ }^{91}$ Per the statute, the eleven members "shall include at least three architects, one historian qualified in the field, one city planner or landscape architect, and one realtor." ${ }^{92}$ The mayor appoints the commissioners. ${ }^{93}$ All but one receive no salary. ${ }^{94}$ The Commission also employs about sixty full-time staff, including "architects, architectural historians, restoration specialists, planners, and archaeologists, as well as administrative, legal, and clerical personnel." "95 Various departments carry out functions such as awarding restorations grants to homeowners, researching proposed landmarks, assisting applicants with proper building materials, and ensuring

87. See N.Y.C., N.Y., Admin. CodE $\S \S 25-301$ - 25-322 (2012).

88. See Planning (Listed Buildings and Conservation Areas) Act, 1990, c. 9, §§ 1-94 (U.K.).

89. About LPC, N.Y.C. LANDMARKS PRES. COMM'N, http://www.nyc.gov/html/ $\mathrm{lpc} / \mathrm{html} /$ about/about.shtml (last visited Mar. 10, 2013, archived at http://perma.cc/3TWMSFWQ); see also ADMIN. § 25-301(a).

90. AdMIN. § 25-301(b).

91. James Barron, Celebrating 45 Years of Preserving New York, N.Y. TiMES (Apr. 19, 2010, 6:15 PM), http://cityroom.blogs.nytimes.com/2010/04/19/celebrating-45-years-ofpreserving-new-york/, archived at http://perma.cc/TKJ7-KKUH.

92. N.Y.C., N.Y., CHARTER § 3020(1) (1989); see also FAQ: About the Landmarks Preservation Commission, N.Y.C. LANDMARKS PRES. COMM'N, http://www.nyc.gov/html/ lpc/html/faqs/faq_about.shtml (last visited Nov. 29, 2013, archived at http://perma.cc/EQP4LBXD).

93. Charter $\S \S 31,3020(2)(\mathrm{a})$; see also About LPC: Commissioners, N.Y.C. LANDMARKS PRES. COMM'N, http://www.nyc.gov $/ \mathrm{html} / \mathrm{lpc} / \mathrm{html} / \mathrm{about} / \mathrm{about}$ commissioners.shtml (last visited Nov. 6, 2013, archived at http://perma.cc/4LFG-K8RV).

94. CHARTER $\S 3020(3)$.

95. FAQ: About the Landmarks Preservation Commission, supra note 92. 
compliance with the NYC Act. ${ }^{96}$

The procedure for listing a site as a landmark under the NYC Act has been described as "daunting." "97 However, the opportunity to nominate a landmark is accessible to all; the Commission welcomes suggestions from interested citizens, asking them to submit a simple, one-page Request for Evaluation and to attach photographs if possible. ${ }^{98}$ Commission members and staff may also identify potential landmarks themselves. ${ }^{99}$

The Commission decides if a proposal merits further consideration, then votes on whether to schedule a public hearing, ${ }^{100}$ which the NYC Act requires before any designation. ${ }^{101}$ The Commission must put a notice of an upcoming hearing in the City Record and give notice directly to the owner of the parcel on which a landmark designation has been proposed. ${ }^{102} \mathrm{At}$ these hearings,

the commission shall afford a reasonable opportunity for the presentation of facts and the expression of views by those desiring to be heard, and may, in its discretion, take the testimony of witnesses and receive evidence; provided, however, that the commission, in determining any matter as to which any such hearing is held, shall not be confined to consideration of the facts, views, testimony or evidence submitted at such hearing. ${ }^{103}$

A member of the Commission's Research Department also presents a report at the hearing. ${ }^{104}$

Then, the Commission holds a vote. ${ }^{105}$ If six or more members of the Commission vote to designate the proposed property, the protections of the

96. About LPC: Departments, N.Y.C. LANDMARKS Pres. COMM'N, http://www.nyc.gov/html/lpc/html/about/departments.shtml (last visited Nov. 6, 2013, archived at http://perma.cc/ZRH8-2N8U).

97. Birmingham, supra note 68 , at 279.

98. Propose a Landmark, N.Y.C. LANDMARKS Pres. COMM'N, http://www.nyc.gov/html/lpc/html/propose/landmark.shtml (last visited Nov. 6, 2013, archived at http://perma.cc/D3KZ-BSFF). A copy of the request form is available at http://www.nyc.gov/html/lpc/downloads/pdf/forms/request_for_evaluation.pdf, archived at http://perma.cc/PS6R-XMYZ.

99. FAQs: The Designation Process, N.Y.C. LANDMARKS Pres. COMM'N, http://www.nyc.gov/html/lpc/html/faqs/faq_designation.shtml (last visited Nov. 6, 2013, archived at http://perma.cc/N94L-UY6R).

100. Id.

101. N.Y.C., N.Y., Admin. CodE § 25-303 (2012).

102. Id. § 25-313(a); FAQs: The Designation Process, supra note 99.

103. ADMIN. § 25-313(b); see also FAQs: The Designation Process, supra note 99.

104. FAQs: The Designation Process, supra note 99.

105. FAQs: The Designation Process, supra note 99. 
NYC Act go into effect immediately. ${ }^{106}$ But the designation process still is not complete. Next, the City Planning Commission enters the mix and must hold its own public hearing ${ }^{107}$ and submit to the City Council a report "on the effects of the designation as it relates to zoning, projected public improvements, and any other city plans for the development or improvement of the area involved." 108

The City Council may modify or disapprove a landmark designation by a majority vote. ${ }^{109}$ All votes are filed with the Mayor, who is allowed to veto the decision; the Council may then override the veto with a two-thirds vote. $^{110}$

Once designated, the Act provides significant protection to the building's preservation:

Once a building is officially designated a landmark, significant limitations apply to construction projects undertaken at the building's site. Most alterations, especially those that affect the remarkable architectural aspects of a building, must be submitted to and approved by the Landmarks Commission. However, minor exterior work and maintenance does not require the Commission's approval. ${ }^{111}$

In addition, designated building owners must maintain a state of good repair. $^{112}$

An official landmark designation in New York City, however, does not mean a complete and indefinite ban on all building alterations. Through a system of three different permits, the Commission may approve alterations to a landmark in some instances.

First, the Commission may issue a "certificate of no effect" (CNE) "when the proposed work ... does not affect the protected architectural features of a building" or "detract from the special character of a historic

106. FAQs: The Designation Process, supra note 99; ADMIN. § 25-303(e).

107. ADMIN. § 25-303(g)(1)(a).

108. FAQs: The Designation Process, supra note 99; see also ADMIN. § 25-303(g)(1)(b).

109. ADMIN. § 25-303(g)(2).

110. Id.

111. Birmingham, supra note 68, at 280; see also ADMIN. § 25-305 (making it unlawful to "alter, reconstruct or demolish any improvement" that is part of a designated landmark site or in a designated historic district); FAQs: Making Changes to a Landmarked Building, N.Y.C. LANDMARKS PRES. COMM'N, http://www.nyc.gov $/ \mathrm{html} / \mathrm{lpc} / \mathrm{html} / \mathrm{faqs} /$ faq_permit.shtml (last visited Nov. 8, 2013, archived at http://perma.cc/RLD9-5VPR) ("You do not need a permit from the Landmarks Commission to perform ordinary repairs or maintenance chores.").

112. ADMIN. § 25-311. 
district." $" 113$ An example of work that may be permitted with a CNE is installation of plumbing and heating equipment. ${ }^{114}$

Second, the Commission may issue a "permit for minor work" (PMW) when the work does not require a building permit from the city, but does affect protected features of the landmark. ${ }^{115}$ Examples of work that would require a PMW are window replacement and restoration of architectural details. ${ }^{116}$ The Commission evaluates the appropriateness of such work before approving the permit. ${ }^{117}$

The third and last permit is a "certificate of appropriateness" ( $\mathrm{C}$ of $\mathrm{A})$. Work such as "[a]dditions, demolitions, new construction, and removal of architectural features" that "will affect significant protected architectural features" requires a $\mathrm{C}$ of $\mathrm{A} .{ }^{118}$ If someone applies for and is denied a CNE, he or she may then apply for a $\mathrm{C}$ of $\mathrm{A} .{ }^{119}$ In deciding whether to issue this certificate, the Commission must decide if the proposed work is consistent with the purposes of the NYC Act, ${ }^{120}$ meaning it must "consider . . . the perpetuation and use of the exterior architectural features of such landmark which cause it to possess a special character or special historical or aesthetic interest or value." $" 121$

In response to the NYC Act, the City Planning Commission updated its Zoning Resolution to allow owners of landmark buildings to more easily transfer their unused development rights to adjacent parcels. ${ }^{122}$ This means that a property owner whose development options are limited due to the landmark status of his building can essentially "over"-develop an adjacent lot that he also owns, or he can sell those rights to someone else. ${ }^{123}$ Specifically, the owner of the adjacent parcel may, among other things, increase the normal maximum floor space, ${ }^{124}$ decrease the normal minimum

113. FAQs: Making Changes to a Landmarked Building, supra note 111; see also ADMIN. § 25-306(a)(1).

114. See FAQs: Making Changes to a Landmarked Building, supra note 111.

115. FAQs: Making Changes to a Landmarked Building, supra note 111.

116. FAQs: Making Changes to a Landmarked Building, supra note 111.

117. FAQs: Making Changes to a Landmarked Building, supra note 111; see also ADMIN. § 25-310.

118. FAQs: Making Changes to a Landmarked Building, supra note 111. A public hearing is held, and at least six Commission members must vote in favor. FAQs: Making Changes to a Landmarked Building, supra note 111. "The actual C of A permit is not issued until the staff has reviewed the final construction drawings to make sure that the final plans are consistent with the proposal approved by the Commissioners." FAQs: Making Changes to a Landmarked Building, supra note 111.

119. ADMIN. § 25-307(a).

120. Id.

121. Id. $\S 25-307(\mathrm{~d})$.

122. See N.Y.C., N.Y., Zoning Resolution § 74-79 (1969).

123. See id.

124. "The floor area of a building is the sum of the gross area of each floor of the building, excluding mechanical space, cellar space, floor space in open balconies, elevators 
open space, ${ }^{125}$ and vary from normal front height and setback ${ }^{126}$ regulations. ${ }^{127}$ The amendment redefined "adjacent" to include parcels across a street or intersection from a designated landmark. ${ }^{128}$

The Commission, in enacting this more flexible rule, recognized that "quite a few of the landmarks most valuable to preserve for aesthetic and historic reasons are also located on lots whose economic potential greatly exceeds their present use. The proposed amendments would permit the owners of designated landmarks to realize some of this potential value without destroying their landmarks."129

However, there are also limits on how much a property owner can stray from the usual zoning regulations on the adjacent property. For example, a building's floor space may be increased only up to 20 percent. ${ }^{130}$ Such limits were put in place "to promote architecture that will relate to and enrich the area surrounding the City's landmarks" and to ensure "no single zoning lot will become burdened with an excessive concentration of bulk." ${ }^{131}$ New York City's transferable development rights seem to attempt to strike a balance between property owners' rights and the recognized values of architectural preservation.

It is possible to rescind a property's designation as a landmark under the NYC Act. The rescission process is very similar to the complex steps required for designation in the first place: a public hearing, a City Planning Commission report, review by the City Council, and review by the Mayor. ${ }^{132}$ In reality, though, the rescission option is not often used. ${ }^{133}$

A federally funded grant program is available to certain New York

or stair bulkheads and, in most zoning districts, floor space used for accessory parking that is located less than 23 feet above curb level." NYC Zoning - Glossary, N.Y.C. DEP'T OF CiTY PLANNING, http://www.nyc.gov/html/dcp/html/zone/glossary.shtml (last visited Nov. 8, 2013, archived at $\mathrm{http}: / /$ perma.cc/KM6B-QW48).

125. Id. ("Open space is the part of a residential zoning lot (which may include courts or yards) that is open and unobstructed from its lowest level to the sky, except for specific permitted obstructions, and accessible to and usable by all persons occupying dwelling units on the zoning lot.").

126. Id. ("A setback is the portion of a building that is set back above the base height (or street wall or perimeter wall) before the total height of the building is achieved. The position of a building setback in height factor districts is controlled by sky exposure planes and, in contextual districts, by specified distances from street walls.").

127. ZONING RESOLUTION $§ 74-79$.

128. Sarah J. Stevenson, Note, Banking on the TDRS: The Government's Role as Banker of Transferable Development Rights, 73 N.Y.U. L. REV. 1329, 1334 (1998); ZONING RESOLUTION $\S 74-79$.

129. N.Y.C. Planning COMM'N, REPORT CP-20253 (1968), archived at http://perma.cc/4N46-3KHP.

130. ZONING RESOLUTION § 74-792(b)(4).

131. N.Y.C. PLANNING COMM'N, supra note 129.

132. See N.Y.C., N.Y., Admin. Code $§ 25-303($ h) (2012).

133. Joachim Beno Steinberg, Note, New York City's Landmarks Law and the Rescission Process, 66 N.Y.U. ANN. SuRv. AM. L. 951, 972 (2011). 
City homeowners and nonprofits that need to do exterior restoration or repair work on their landmark properties. ${ }^{134}$ Other grants and loans are offered through private organizations, such as the New York Landmarks Conservancy. ${ }^{135}$

The NYC Act was put to the test in the United States Supreme Court in 1978. Penn Central Transportation, the owner of Grand Central Terminal in New York City - an eight-story building that opened in $1913^{136}$ claimed "that the application of the Landmarks Preservation Law had 'taken' their property without just compensation in violation of the Fifth and Fourteenth Amendments . . .."137 The terminal had been designated a landmark under the NYC Act "as a magnificent example of the French beaux-arts style," 138 and the owners sought permission to construct an office building on top of the terminal. ${ }^{139}$ The plaintiffs submitted two different plans, both of which the Commission rejected, stating that an office building on top of the beaux-arts terminal would be an "aesthetic joke." The Commission went on to say that urban design must be preserved "in a meaningful way - with alterations and additions of such character, scale, materials and mass as will protect, enhance and perpetuate the original design rather than overwhelm it." 141

Significant in the Penn Central case was the Supreme Court's affirmation that historical preservation laws are related to the public's health, safety, morals, or general welfare. ${ }^{142}$ The Court held there was no taking because the NYC Act's restrictions were "substantially related to the promotion of the general welfare," and they still allowed "reasonable beneficial use" of the building and left the owners with other opportunities to alter it. ${ }^{143}$ The Court specifically noted that the plaintiffs had not sought approval of any alternate construction, and there was no reason to believe that the Commission would deny all construction above the terminal. ${ }^{144}$ The Court also explained that the transferable development rights ${ }^{145}$ help

134. See About LPC: Historic Preservation Grant Program, N.Y.C. LANDMARKS PRES. CoMm'N, http://www.nyc.gov/html/lpc/html/about/hpgp.shtml (last visited Nov. 8, 2013, archived at http://perma.cc/P2X4-PGLP).

135. See Programs \& Services, N.Y. LANDMARKS CONSERVANCY, http://www.nylandmarks.org/programs_services/ (last visited Nov. 8, 2013, archived at http://perma.cc/XHQ6-2DDC).

136. Penn Cent. Transp. Co. v. City of N.Y., 438 U.S. 104, 115 (1978).

137. Id. at 109.

138. Id. at 115 .

139. Id. at 116 .

140. Id. at 116-18.

141. Id. at 118 .

142. See id. at 125 .

143. Id. at 138 .

144. Id. at $136-37$.

145. See supra notes $122-23$ and accompanying text. 
"mitigate whatever financial burdens the law has imposed on [plaintiffs] ...."146

The Landmarks Preservation Commission is central to the landmark designation process in New York City. It facilitates the review of proposed landmarks and is the first step in approval. The Commission interacts with the public and addresses community concerns. Most alterations to a landmarked building require approval by the Commission in order to protect the building's unique features. However, the Zoning Resolution's transferable development rights provide an alternative for developers when the landmark status of their property would otherwise limit their options. Rescission of landmark status is possible but rare-an issue that is discussed in more detail in section $\mathrm{V}$.

\section{Success and Criticism of the NYC Act}

The NYC Act has both fans and critics. Under the NYC Act, more than 1000 individual buildings in the city's five boroughs have been landmarked; that number does not include buildings within designated historic districts. ${ }^{147}$ New York City residents who remember the destruction of Pennsylvania Station would likely say the NYC Act has helped prevent other beloved buildings from experiencing a similar fate. ${ }^{148}$ Overall, the NYC Act seems to recognize and successfully protect the various values associated with a city's built environment. ${ }^{149}$

On the other hand, some believe the attitude that historic districts and buildings should stay exactly the same is "inconsistent with [New York's] nature and identity as a city." ${ }^{, 150}$ Another critic, Edward Glaeser, says the NYC Act has led to over-landmarking, impeding new construction and making real estate prices go up. ${ }^{151}$ In addition, Glaeser says many of the buildings in designated historic districts are "uninteresting" and "less

146. Penn Cent., 438 U.S. at 137 (alterations added).

147. As of 2008, the count was near 1200 individual landmarks. N.Y. LANDMARKS PRES. COMm'n, Guide to New York City Landmarks (4th ed., 2008). The number of buildings within designated historical districts is much higher-around 25,000. Edward L. Glaeser, Preservation Follies: Excessive Landmarking Threatens to Make Manhattan a Refuge for the Rich, City Journal (2010), archived at http://perma.cc/X6T5-7PWV.

148. Pennsylvania Station was a massive, ornate Beaux-Arts style building erected in New York City in 1910, and it was torn down over a three-year period starting in 1963. Pennsylvania Station, N.Y. PRES. ARCHIVE PROJECT, http://www.nypap.org/content/ pennsylvania-station (last visited Nov. 8, 2013, archived at http://perma.cc/7BZJ-PYKU). Many consider Penn Station's destruction a factor in the passing of the NYC Act because it "increased public awareness of the need to protect the city's architectural, historical, and cultural heritage." About LPC, supra note 89.

149. See supra Part III.A.

150. Barron, supra note 91.

151. See Glaeser, Preservation Follies, supra note 147, at 5. 
attractive and exciting than new structures that could replace them." 152

Also a critic of the NYC Act, Justice Rehnquist in his dissent to the Penn Central decision articulated concern that the Act placed the costs of preservation entirely on the shoulders of those who happen to own landmarked buildings. ${ }^{153}$ He noted that at the time Grand Central Station was designated as a landmark, the owners were in financial trouble, making it difficult for them to comply with the requirements of the NYC Act. ${ }^{154}$

The NYC Act also faces criticism from preservationists who think the city could be doing more to efficiently and effectively designate landmarks. Many preservationists will attest that the designation process in New York is long, and many requests come to a dead end. ${ }^{155}$ The New York Times carried out a six-month investigation of the Landmarks Preservation Commission, in which it found the Commission was "an overtaxed agency that has taken years to act on some proposed designations." "156 An even bigger issue for some preservationists is the way Requests for Evaluations are handled. ${ }^{157}$ The Requests are funneled through the Commission chair Robert Tierney - who has no architectural or planning expertise - and his staff. $^{158}$ The rest of the Commission does not see many of the Requests. ${ }^{159}$

Finally, the NYC Act's rescission process is weak and rarely used. ${ }^{160}$ Landmark status for perpetuity may not be appropriate in every circumstance, yet the law provides little guidance or opportunity for dedesignating a building. ${ }^{161}$

152. Glaeser, Preservation Follies, supra note 147, at 5.

153. Penn Cent. Transp. Co. v. City of N.Y., 438 U.S. 104, 139 (1978) (Rehnquist, J., dissenting). For more commentary on Justice Rehnquist's dissent in Penn Central, see generally Chauncey L. Walker \& Scott D. Avitabile, Regulatory Takings, Historic Preservation and Property Rights Since Penn Central: The Move Toward Greater Protection, 6 FoRdHAM ENVTL. L.J. 819, 821-25 (2011).

154. Penn Cent., 438 U.S. at 141 (Rehnquist, J., dissenting).

155. Robin Pogrebin, An Opaque and Lengthy Road to Landmark Status, N.Y. TimeS (Nov. 25, 2008), http://www.nytimes.com/2008/11/26/arts/design/26landmarks.html, archived at http://perma.cc/53QP-RA6Q. For example, preservationists in 1998 requested landmark status for the 1940 Tiffany \& Co. store on Fifth Avenue. Id. The Commission replied that it would take the building "under consideration," but did not respond again until three years later, after the group resubmitted its request. Id. This time, the response said the Tiffany building was potentially eligible, but still no further action has been taken a decade later. Id.

156. Id.

157. $I d$.

158. Id.

159. Id.

160. See generally Steinberg, supra note 133.

161. See Steinberg, supra note 133, at 971. 


\section{B. The United Kingdom's Planning (Listed Buildings and Conservation Areas) Act}

\section{Overview of the Act and Related Authority}

The U.K. Planning (Listed Buildings and Conservation Areas) Act (hereinafter U.K. Planning Act) was enacted in 1990. ${ }^{162}$ The government's prerogative in enforcing the Act "is that the historic environment and its heritage assets should be conserved and enjoyed for the quality of life they bring to this and future generations." 163 Planning objectives include sustainable development, conservation, and education. ${ }^{164}$

As in New York City, the United Kingdom has a process for listing buildings in order to protect them from alteration and destruction. A building may be listed" ${ }^{165}$ only if it has "special architectural or historic interest." "Architectural interest" may be present in buildings with important design, decoration, or craftsmanship, or in buildings that display technological innovation. ${ }^{167}$ "Historic interest" may be present in buildings that "illustrate important aspects of the nation's social, economic, cultural, or military history and/or have close historical associations with nationally important people." 168 In the United Kingdom, the government and English Heritage provide extensive guidance for deciding what sorts of buildings are worthy of listing. ${ }^{169}$

The United Kingdom's regime divides listed buildings into three categories depending on their level of importance: Grade I is the highest

162. Planning (Listed Buildings and Conservation Areas) Act, 1990, c. 9, §§ 1-94 (U.K) [hereinafter U.K. Planning Act].

163. Dep't for Cmtys. and Local Gov't, Planning Policy Statement 5: Planning FOR THE Historic ENVIRONMENT, 2010, at 2 (U.K.) [hereinafter PPS5]. Planning policy statements are documents that describe national policies on various aspects of planning in England; PPS5 contains policies regarding historical conservation. Id. at 1 . The policies apply to planning authorities' responsibilities under the U.K. Planning Act. Id.

164. Id. at 2 .

165. In the context of the U.K. Planning Act, saying a building is "listed" is the equivalent of saying it has been officially designated as a landmark.

166. U.K. Planning Act $\S 1$.

167. Dept. for Culture, Media and Sport, Principles of Selection for Listing BuILDINGS 4 (2010) (U.K.), archived at http://perma.cc/QBZ9-MY9Z.

168. Id.

169. The Department for Culture, Media and Sport has published a general set of principles to be applied by the Secretary of State. See id. In addition, English Heritage has published its own guidelines for selecting heritage assets for designation. Listing Selection Guides, English HeRITAge, http://www.english-heritage.org.uk/caring/listing/criteria-forprotection/selection-guidelines/ (last visited Nov. 9, 2013). There are twenty different publications for building selection alone, each one focusing on a particular genre of buildings, such as Places of Worship, Industrial Structures, Commemorative Structures, and various types of Domestic Structures. Id. 
category and applies to the smallest number of listed buildings; Grade II* ("two plus") is the intermediate category; and Grade II, the lowest designation, applies to the majority of listed buildings and is the most common category for homes. ${ }^{170}$

The Secretary of State for Culture, Olympics, Media and Sport assigns listed building status, either by his or her independent decision, or by the suggestion of the Historic Buildings and Monuments Commission for England or other persons or groups. ${ }^{171}$ The Commission, now commonly known as English Heritage, is an executive non-departmental public body that manages historical sites and monuments and advises the government and local authorities, among other functions. ${ }^{172}$ English Heritage is a commission of up to seventeen people who the Secretary of State appoints based on their skills or professions in special areas of expertise. ${ }^{173}$ Many current members have previous experience in government and in various museums. ${ }^{174}$

Before officially listing a building, the Secretary must consult with English Heritage or "with such other persons or bodies of persons as appear to him appropriate as having special knowledge of, or interest in, buildings of architectural or historic interest." 175 It is English Heritage who reviews applications from the public, researches the suggested buildings, and puts together reports on their historical background. ${ }^{176}$ English Heritage may play a key role in recommending a building for listing, although the final listing decision belongs to the Secretary of State. ${ }^{177}$

170. Listed Buildings, ENGLish HeRITAGE, http://www.english-heritage.org.uk/ caring/listing/listed-buildings/ (last visited Nov. 9, 2013, archived at http://perma.cc/6HMGJ8SY).

171. U.K. Planning Act $\S 1(1)$. The public application form is archived at http://perma.cc/QY5J-CPSM.

172. What English Heritage Does, English Heritage, http://www.englishheritage.org.uk/about/who-we-are/how-we-are-run/what-we-do/ (last visited Nov. 10, 2013, archived at $\mathrm{http}: / /$ perma.cc/A5FR-D6AS).

173. The Commission at English Heritage, English Heritage, http://www.englishheritage.org.uk/about/who-we-are/how-we-are-run/commission/ (last visited Nov. 10, 2013, archived at http://perma.cc/53RS-DAY4).

174. See Executive Board Member Biographies, English HeritAGE, http://www.englishheritage.org.uk/about/who-we-are/how-we-are-run/executive-board/biographies/ (last visited Nov. 28, 2013, archived at http://perma.cc/J8KV-SBNS). For example, Chief Executive Simon Thurley was Director of the Museum of London and Curator of Historic Royal Palaces before becoming a member of the English Heritage Executive Board. See Biography, SimONTHuRLEY.COM, http://www.simonthurley.com/bio.html (last visited Nov. 10, 2013, archived at http://perma.cc/T3UD-5G84).

175. U.K. Planning Act $\S 1(4)$.

176. Consultation Process, ENGLish Heritage, http://www.englishheritage.org.uk/caring/listing/listed-buildings/consultation-process/ (last visited Nov. 10, 2013, archived at $\mathrm{http}: / /$ perma.cc/ZCQ3-UXAW).

177. See U.K. Planning Act $\S 1$. 
The U.K. Planning Act also provides for temporary building preservation notices in the event that an unlisted building of architectural or historic interest is in danger of demolition or damaging alteration. ${ }^{178} \mathrm{~A}$ building preservation notice will stay in force for up to six months, during which time the building is treated as if it were a listed building. ${ }^{179}$ In the meantime, the Secretary of State may decide whether or not to permanently list the building. ${ }^{180}$

Once a building is listed, subject to certain provisions, no one may demolish, alter, or extend it "in any manner which would affect its character as a building of special architectural or historic interest, unless the works are authorised." 181 A proposed alteration, extension, or demolition of a listed building may be authorized by the written consent of the local planning authority. ${ }^{182}$ Local planning authorities will seek the expert advice of the English Heritage Commission if the consent request involves a Grade I or II* building, a demolition, or a particularly complicated case. ${ }^{183}$

When the local planning authority or Secretary of State considers whether to grant consent for alteration, extension, or demolition, it "shall have special regard to the desirability of preserving the building or its setting or any features of special architectural or historic interest which it possesses." ${ }^{\prime 184}$ A consent decision should be a balancing act weighing the significance of the heritage asset against the desirability of new development. ${ }^{185}$ In a 2009 case, English Heritage challenged a Secretary of State decision to permit the construction of a mixed-use site in London that would have an impact on a Grade I listed building, Somerset House. ${ }^{186}$ The Secretary believed the site would bring important social benefits such as employment and local economic growth. ${ }^{187}$ Deciding that these factors outweighed the damage to Somerset House, the judge did not quash the permit. ${ }^{188}$

When the planning authority or Secretary consents to the alteration, extension, or demolition of a listed building, it may do so subject to certain

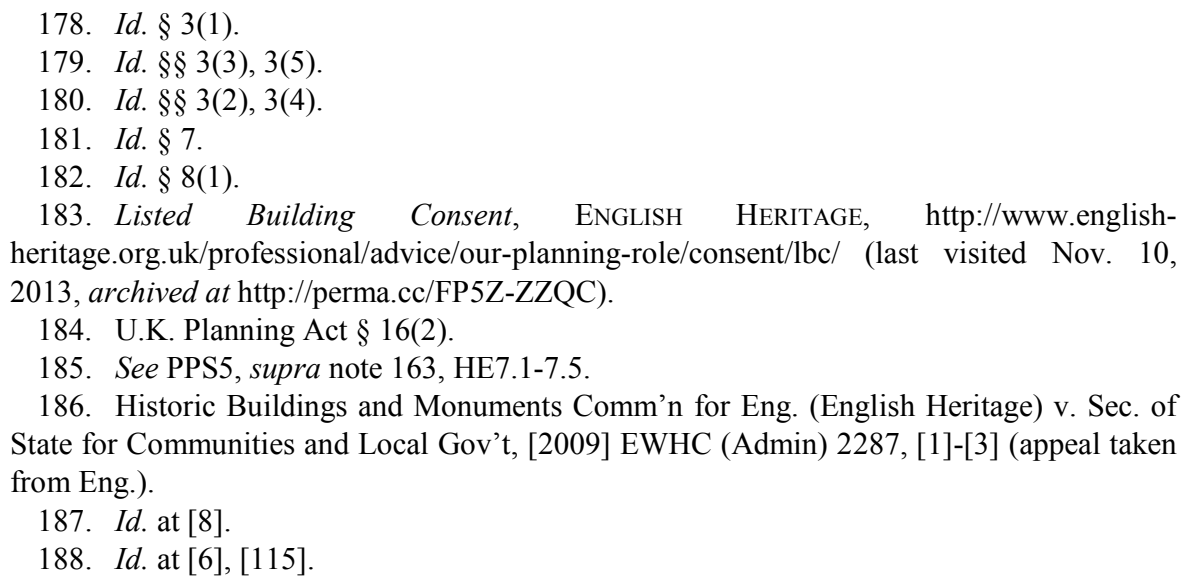


conditions. It may require the preservation of certain building features or the repair or reconstruction of any damage that occurs during the course of the work. ${ }^{189}$

English Heritage offers landmark owners the opportunity to apply for grants to pay for urgent structural repairs on Grade I and Grade II* buildings. ${ }^{190}$ Owners can also pursue grants through various charitable organizations. $^{191}$

As in New York, landmark status in the United Kingdom can be rescinded, or "de-listed." Requests for de-listing are made to the English Heritage Commission just like listing applications and should include evidence supporting the de-listing. ${ }^{192}$ An application for de-listing may be appropriate when new evidence suggests the building does not have special historical or architectural interest, or when the building's circumstances have materially changed. ${ }^{193}$

The decision process for de-listing is complex-taking about five months ${ }^{194}$ - but it is clearly laid out. ${ }^{195}$ The Commission makes an initial assessment of the application before notifying the local authority, at which point owners and local planners can submit feedback. ${ }^{196}$ The Commission inspects the building and publishes a report describing the building's history and other background information. ${ }^{197}$ After considering all the relevant responses to its report, the Commission makes its recommendation to the Secretary of State. ${ }^{198}$ The Secretary of State will de-list a landmark only if it no longer meets the "special architectural or historic interest" standard; he may not take into account any other considerations. ${ }^{199}$ The Commission receives an average of 150 requests per year, about half of which lead to a de-listing. ${ }^{200}$

189. U.K. Planning Act $§ 17(1)$.

190. See Grants for Historic Buildings, Monuments and Designed Landscapes, ENGLISH

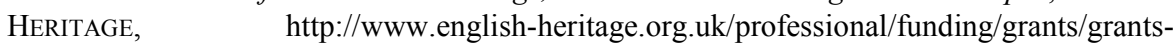
available/hbmdl/ (last visited Feb. 9, 2013, archived at http://perma.cc/D2D9-ENQ3).

191. See generally FunDS FOR HistORIC BUILDINGS, http://www.ffhb.org.uk/ (last visited Nov. 28, 2013, archived at http://perma.cc/8YH2-3Q33). A directory of funding sources is maintained at the Funds for Historic Building's website at http://www.ffhb.org.uk/results.php?action=full, archived at http://perma.cc/T3ET-9GQW.

192. English Heritage, RemOving A Building From the List 2 (2010) (U.K.), archived at http://perma.cc/9VPG-QVE2.

193. Id. at 1.

194. Id. at 3.

195. See generally id.

196. Id. at 2 .

197. Id. at 3 .

198. Id.

199. Id. at 1 .

200. Id. at 3 . 


\section{SUGGESTIONS FOR ADACH'S MODERN HERITAGE PRESERVATION INITIATIVE}

\section{A. How Abu Dhabi and ADACH Can Draw Guidance from the NYC Act and the U.K. Planning Act}

The architectural preservation regimes in New York City and London can serve as a jumping-off point for $\mathrm{ADACH}$ as it works toward an effective regime for Abu Dhabi. The former cities have many things in common when it comes to how they choose to preserve their architectural heritage: they have a similar policy behind their laws, they employ a special commission, they encourage public participation, they provide similar protections for landmarks, they use a permit system for alterations, and they allow for rescission of landmark status. Each city also has unique features that may be of interest to ADACH: New York City allows for transferable development rights, and the United Kingdom provides for a temporary listing. While New York City and London's programs can provide valuable guidance to a new city's quest for effective preservation laws, they need to be adapted to fit a modern city such as Abu Dhabi. This section addresses which aspects of the NYC and UK programs Abu Dhabi should replicate, which it should ignore, and which it should adapt.

\section{Underlying Policies}

In general, it seems that New York City's policy reasons for enacting its landmark law are similar to Abu Dhabi preservationists' beliefs. ${ }^{201} \mathrm{New}$ York saw buildings destroyed unnecessarily to the detriment of the city, ${ }^{202}$ just like what is happening currently in Abu Dhabi. Thus, the NYC Act's policy statement might be a good starting point for ADACH. However, New York's goals to protect, enhance, and perpetuate use of landmarks clearly are bent strongly toward preservation and little change. Similarly, the United Kingdom's policy of conserving heritage assets for future generations $^{203}$ seems to strongly favor conservation. Considering Abu Dhabi's ever-changing landscape, perhaps an appropriate verb to add to its policy statement would be "manage." Management of landmarks suggests a recognition of landmark buildings' value, but also suggests a mindfulness of changing circumstances and of the competing interests within a

201. See N.Y.C., N.Y., Admin. CodE § 25-301(b) (2012) ("It is hereby declared as a matter of public policy that the protection, enhancement, perpetuation and use of improvements and landscape features of special character or special historical or aesthetic interest or value is a public necessity and is required in the interest of the health, prosperity, safety and welfare of the people.").

202. Recall the destruction of Pennsylvania station, discussed supra note 148.

203. See supra note 163 and accompanying text. 
community.

\section{A Commission to Facilitate Preservation}

The Landmarks Preservation Commission and English Heritage are integral to the landmark designation processes in New York City and London, respectively. It is important to have a group of people dedicated to making the important decision of what buildings are worthy of special treatment, especially because the special treatment may limit property owners' rights. English Heritage seems to be a rather loose assembly of people deemed worthy of commission membership for unclear reasons. ${ }^{204}$ New York's commission, on the other hand, is a good model for Abu Dhabi because the statute requires it to include professionals of diverse backgrounds who represent sometimes competing views. ${ }^{205}$ In Abu Dhabi, a good way to manage preservation and development within the landmark designation process would be to institute a commission of people with varied viewpoints.

A historian would be valuable for his knowledge of the intricacies of Abu Dhabi's past and how it became the city that it is today. An architect would have an understanding of the relative importance and quality of various buildings. An Islamic scholar would also be valuable because Abu Dhabi is part of a Muslim nation, so religion is an integral part of everyday life. A city planner would be important for her expertise on how a landmarked building would fit in with its surroundings, and on how future development might affect the building and its neighborhood. Someone with experience in real estate and development would also be critical in Abu Dhabi's commission, because he could represent views opposite to preservationists and help facilitate compromises. These are just a few examples of individuals who would help comprise an effective landmark committee in Abu Dhabi.

\section{The Building Selection Process}

The New York and London procedures for selecting buildings for designation may also provide guidance for Abu Dhabi. First, both cities allow members of the public to suggest buildings for landmark consideration. $^{206}$ This only seems appropriate considering architectural

204. The English Heritage commission was not created under the U.K. Planning Act. According to English Heritage's website, "[t]he Commission comprises a maximum of 17 individuals, appointed by the Secretary of State for the Department for Culture, Media and Sport, for their skill or professional standing in one or more areas of expertise." The Commission at English Heritage, supra note 173 (alteration added).

205. See supra text accompanying note 92.

206. See supra text accompanying notes 98 and 171. 
preservation laws are intended to benefit the welfare of the public. ${ }^{207} \mathrm{New}$ York also holds public hearings, which again allow the people who are supposed to be benefitted to express their views. In Abu Dhabi, it would be difficult for a government commission to make a determination of "the public's" best interests without a public hearing. Abu Dhabi natives with more of a connection to the local culture may feel particularly invested in the future of buildings in their neighborhoods. Wealthy developers likely want to ensure they will have options to build in the future. Real estate owners might desire landmark recognition for their buildings, or they might worry about the costs and obligations of owning a landmark. All of these views can be aired at a public hearing and weighed by the committee.

When it comes time to make the final decision to designate, the United Kingdom's approach seems simpler, while the New York approach involves more steps but is more democratic. ${ }^{208}$ The downside to the United Kingdom's process is that allowing one person to have the say over experts could defeat the purpose of having a diverse commission. However, if the final decision-maker is simply a formality, and he or she adheres to the commission's suggestion, a conflict may be avoided. The downside to New York's approach, of course, is that there are more steps and more government entities involved, which only increases the danger that political agendas will influence outcomes of decisions. ${ }^{209}$ In New York City, it is really the City Council that makes the decision whether a building receives landmark status. ${ }^{210}$ Thus there exists the same potential problem as in the United Kingdom, where a "higher up" government entity can easily overrule the carefully crafted and diversely educated commission.

Perhaps it is impossible to craft the perfect landmark designation process that avoids the aforementioned problems. For Abu Dhabi, the final decision-maker should be required by law, at a minimum, to consult with the commission and others with special knowledge or interest in the building. Such a requirement would resemble Section 1(4) of the U.K. Planning Act. ${ }^{211}$ The decision-maker must then be held accountable for any

207. See supra text accompanying note 77.

208. Recall that in the United Kingdom, the Secretary of State for Culture, Media and Sport makes the final listing decision. See supra note 177 and accompanying text. In New York City, the Landmarks Preservation Commission votes, then the City Council votes, then the mayor may veto, and the Council may override the veto. See supra notes 105-10 and accompanying text.

209. See Birmingham, supra note 68, at 295 (noting that some preservationists have suggested the Commission has avoided designating landmarks when the mayor has endorsed a construction plan on the site or when the site is owned by a group with political clout).

210. See supra notes $109-10$ and accompanying text.

211. See U.K. Planning Act $\S 1(4)$ ("Before compiling, approving (with or without modifications) or amending any list under this section the Secretary of State shall consult(a) in relation to buildings which are situated in England, with the [English Heritage] Commission; and (b) with such other persons or bodies of persons as appear to him 
decisions that are clearly arbitrary or without proper support.

The question of what sorts of buildings are worthy of landmark protection is central to the preservation conflict in Abu Dhabi. ${ }^{212}$ Therefore, one of the key parts of ADACH's initiative will be to develop policies outlining which kinds of structures are important to preserve. The United Kingdom does a better job than New York City of articulating exactly how buildings should be evaluated and which buildings are worthy of landmark status. ${ }^{213}$ Abu Dhabi should publish similar guidelines - whether in statutes or in official policy statements - to establish standards for its landmarks commission to follow.

Of course, the standards for designation in London (and the United Kingdom in general) are very different from standards that would likely be promulgated in Abu Dhabi. London's history goes back many centuries, and the city is still home to numerous buildings from the medieval period to Victorian times. ${ }^{214}$ Despite the vast differences in London's and Abu Dhabi's architectural histories, Abu Dhabi could still use the basic standard of "special architectural or historical interest" from the U.K. Planning Act, ${ }^{215}$ but define that interest based on its own unique situation. In Abu Dhabi, perhaps "special architectural interest" would mean particular Islamic architectural features and innovative building technologies. Perhaps "special historical interest" would mean pre-oil boom buildings and rare examples of past architectural trends.

While many elements of New York's and the United Kingdom's statutes for designating landmarks are effective in their respective jurisdictions, some standards for selecting landmark-worthy structures would be less effective in Abu Dhabi. Most importantly, the NYC Act defines "landmark" to mean "any improvement" that, inter alia, is at least thirty years old. ${ }^{216}$ Therefore, the NYC Act falls short of protecting "modern history," which is exactly what is at issue in Abu Dhabi. However, Abu Dhabi could easily adjust its definition of "landmark" to include a younger age requirement, or no age requirement at all. Considering Abu Dhabi developers are already demolition-happy, an age requirement could create the incentive to demolish buildings just before they reach the necessary age for landmark designation. ${ }^{217}$

appropriate as having special knowledge of, or interest in, buildings of architectural or historic interest.").

212. See generally supra Part II.B.

213. See supra notes 166-69 and accompanying text.

214. See generally London History, BRITAIN EXPRESS, http://www.britainexpress.com/ London/history-of-london.htm (last visited Nov. 11, 2013, archived at http://perma.cc/46ZRMJBA).

215. U.K. Planning Act $\S 1$.

216. N.Y.C., N.Y., ADMIN. CodE § 25-302(n) (2012).

217. This happens to some extent in New York City already. See Gregory A. Ashe, Reflecting the Best of Our Aspirations: Protecting Modern and Post-Modern Architecture, 15 CARdozo ArTs \& ENT. L.J. 69, 85 (1997). 
In the United Kingdom, while there is not a statutory age threshold like in the NYC Act, there is a clear "older is better" mentality when it comes to listing buildings. The newer the building is, the stricter the criteria for listing becomes. ${ }^{218}$ The rationale is that if a building is so old that there are few surviving examples of its kind, the more likely it is to have the "special interest" required by the U.K. Planning Act. ${ }^{219}$ Obviously this is not the sort of thinking that ADACH seeks to encourage with its initiative to protect modern heritage. The concern in Abu Dhabi is that in the future, the city might be culturally poorer due to the loss of buildings that were torn down when they were too young to be recognized as culturally significant. The answer to this concern is to place a duty on the current generation to protect buildings - regardless of age - "not only until at least enough time has passed so that the next generation can make a knowledgeable decision about whether to preserve such buildings, but also to leave the next generation a rich heritage to preserve."220

\section{Protections for Landmarked Buildings and Rights for Developers and Property Owners}

Once a building has been officially listed as a landmark, the NYC Act and the U.K. Planning Act both provide essentially the same protection: alterations are generally not allowed if they would affect the special elements that made the building landmark-worthy in the first place. ${ }^{221}$ As the purpose of architectural preservation laws is primarily to preserve, Abu Dhabi would be remiss not to include such a requirement in its regime.

Just as New York City and London permit alterations and demolitions in certain circumstances, so too should Abu Dhabi. The NYC Act describes three named categories of permits depending on the type of work proposed, ${ }^{222}$ while the U.K. Planning Act calls for simply a "consent" to any type of alteration, extension, or demolition. ${ }^{223}$ It does not seem to matter whether the permits or consents are categorized or given special names, as long as the law gives property owners the opportunity to receive permission to make reasonable alterations to their landmarked buildings.

A permit system is necessary to account for the interests of landmark

218. Listed Buildings, English Heritage, supra note 170. All buildings built before 1700 are listed as long as they remain remotely like their original condition. Listed Buildings, ENGLISH HeRITAGE, supra note 170. Only two-tenths of a percent of all listed buildings in the United Kingdom were built after 1945. Listed Buildings, ENGLISH HERITAGE, supra note 170.

219. Dept. For Culture, Media AND Sport, supra note 167, at 5.

220. Ashe, supra note 217, at 72.

221. See supra notes 111 and 181 and accompanying text.

222. See supra notes $113,115,118$ and accompanying text.

223. U.K. Planning Act $\S 8(1)$. 
owners who may have acquired or constructed their buildings before they became designated. In Abu Dhabi, the owner of a relatively new building might be upset and surprised to find out that he must preserve his building exactly as it stands because the government has decided its preservation serves the public's best interests. To expect property owners anywhereand particularly in the fast-growing Abu Dhabi—not to make any updates to their buildings is unreasonable.

The commission responsible for recommending landmarks should also be responsible for approving or denying requests to alter, extend, or demolish those landmarks. U.K. policy nicely lays out considerations for deciding whether to approve a request: First, the commission "should take into account: the desirability of sustaining and enhancing the significance of heritage assets, and of utilising their positive role in place-shaping; and the positive contribution that conservation of heritage assets and the historic environment generally can make to . . communities. . .."224 Second, the commission "should take into account the desirability of new development making a positive contribution to the character and local distinctiveness of the historic environment." ${ }^{225}$ These two considerations address the conflicting views of preservation in Abu Dhabi, and therefore hopefully would lead to appropriate compromises. It would be up to the commission, with its diverse backgrounds and expertise, to decide which consideration should win out in each case. In order to allow more alterations while still protecting heritage assets, the commission should be able to approve a request subject to conditions, as in the U.K. Planning Act. ${ }^{226}$

Assuming there is adequate funding, $\mathrm{ADACH}$ could attempt to provide grants for certain repairs like English Heritage does. ${ }^{227}$ Otherwise, ADACH might seek the cooperation of other private entities-like those in New York City and in England ${ }^{228}$ - willing to provide grants. Financially strapped landmark owners should not be punished for their inability to maintain their buildings and properly preserve important features. Likewise, if the true goal is to preserve important architecture for the benefit of the people of Abu Dhabi, the people should not have to see their landmarks crumble simply because the owner had nowhere to turn for assistance.

While Abu Dhabi's permit system would allow some alterations and even destructions in appropriate circumstances, it would deny many other requests because of the negative impact the proposed work would have on the architectural features of the building. In order to appease those property owners whose requests are denied, New York's transferable development

224. PPS5, supra note 163, HE7.4.

225. PPS5, supra note 163, HE7.5.

226. See supra text accompanying note 189.

227. See supra text accompanying note 190.

228. See supra text accompanying notes 135 and 191. 
rights $^{229}$ would be a particularly good mechanism for Abu Dhabi to institute. ${ }^{230}$ Such a mechanism would allow developers to recoup some of their lost rights and profits while leaving landmarks intact.

When instituting such a rule, ADACH may want to consider the limits and policies of New York's resolution, and whether Abu Dhabi should adopt or redefine those limits and policies. New York only allows transfer of rights to "adjacent" properties, ${ }^{231}$ but Abu Dhabi may want to broaden its geographical limits to provide more opportunities for developers. An extended "receiving area" 232 can have both positive and negative implications. On the one hand, allowing developers to transfer their rights to an unrelated or distant area can mean the receiving area neighbors are burdened with larger buildings and do not feel the benefits of the far-off preservation. ${ }^{233}$ On the other hand, extending the receiving area increases the number of potential TDR purchasers, adding value and increasing the possibility that developers will actually make the transfers. ${ }^{234}$

Extending receiving areas also furthers policy goals of preservation: "For instance, a very tall building near a preserved landmark may ruin the scaled-down effect which the landmark regulation meant to preserve in the first place." 235 New York limits how much over-development is allowed so surrounding buildings will not detract from a landmark and so zoning areas do not become overly concentrated with large buildings. ${ }^{236}$ However, if Abu Dhabi were to implement an extended receiving area, it would not have this same concern.

Another potentially beneficial mechanism for Abu Dhabi is the U.K. Planning Act's provision for temporary or emergency listing of a

229. Recall that New York's Zoning Resolution allows owners of landmarks to transfer development rights to their adjacent properties or sell those rights to other owners of adjacent properties. See N.Y.C., N.Y., Zoning RESOLUTION § 74-79 (1969).

230. For more information and advice on designing transferable rights regimes, see James T.B. Tripp \& Daniel J. Dudek, Institutional Guidelines for Designing Successful Transferable Rights Programs, 6 YALE J. ON REG. 369, $374-77$ (1989) (outlining eight suggestions for transferable rights regimes, covering technical, legal, and institutional considerations).

231. See ZONING RESOLUTION $§ \S 74-79$.

232. The "receiving area" in a TDR program is where landowners use the additional development rights; the "sending area"-usually a preservation area-is where property owners can trade their unused development rights. Matthew P. Garvey, Student Article, When Political Muscle is Enough: The Case for Limited Judicial Review of Long Distance Transfers of Development Rights, 11 N.Y.U. ENVTL. L.J. 798, 800-01 (2003). An "extended" receiving area refers to a TDR program in which the receiving area is far removed from the sending area in distance or character of use. Id. at 799.

233. See id.

234. Id. at 807.

235. Id.

236. See supra note 131. 
building. ${ }^{237}$ Whatever designation process Abu Dhabi ends up creating, it will likely take months - or longer, depending on the commission's workload and available resources - to come to a decision on designating a building. ${ }^{238}$ In New York City, the Commission sometimes "has taken so long to act that the building in question has been demolished or irretrievably altered."239 Adopting the United Kingdom's temporary listing provision would help Abu Dhabi architecture avoid a similar fate.

\section{Removing a Building from Landmark Status}

As mentioned previously, the NYC Act's rescission process is not terribly accessible. For Abu Dhabi, clear and not-too-strict standards for dedesignating landmarks would be advisable. Because of Abu Dhabi's fastpaced development and ever-changing tastes, a building that is thought worthy of saving one year might not retain that value in ten or twenty years. For example, if a building is landmarked because it represents a certain style or genre of architecture, but better examples of that style are built and landmarked later, it may no longer be desirable to protect the former building, especially if the land can be put to more beneficial use. ${ }^{240}$

In other situations, economic circumstances of landmarked property might change, ${ }^{241}$ or the cost of maintaining the property might come to far outweigh the benefits to the city. ${ }^{242}$ Under such circumstances, the owner of the landmarked property should be given the opportunity to prove to the commission that those changes have occurred and that landmark rescission is therefore justified. ${ }^{243}$ While neither the designation nor de-designation of landmarks should be taken lightly, a clear and accessible rescission process could "lead to greater accommodation between preservationists and developers [because] [t] here would be less of a reason to fight landmark designations if they were not perpetual." 244

237. See supra notes $178-80$ and accompanying text.

238. During the 2008 fiscal year, the NYC Landmarks Preservation Commission received about 200 Requests for Evaluation from the public in addition to the Commission's own nominations. See Pogrebin, supra note 155.

239. Pogrebin, supra note 155.

240. See Steinberg, supra note 133, at 991-92 (suggesting that New York City should allow rescission of landmark status "when the landmark is one of the least valuable examples of a style of architecture that is over-protected in the city").

241. Steinberg, supra note 133, at 990.

242. Steinberg, supra note 133, at 994.

243. Steinberg, supra note 133, at 991 ("Placing the burden on owners to show that [a substantial change in conditions] exists would limit the dangers of re-litigation and would still allow for reconsideration when appropriate.”).

244. Steinberg, supra note 133, at 998. Steinberg is of course referring to the fight between preservationists and developers in New York City, but because of the similar conflict in Abu Dhabi, the theory is also applicable here. 
A similar option is to give a building a preliminary listing as a landmark for a certain number of years, at which point the commission would reassess it for its continuing significance as a landmark. If the building has maintained or increased its cultural value, it would gain a more traditional, permanent status as a landmark. If in hindsight, however, the building does not meet the standards for landmark designation, the preliminary designation would be rescinded. ${ }^{245}$

This idea of a preliminary listing is not practiced by New York City or London, but it incorporates the U.K. Planning Act's temporary building preservation notice $^{246}$ and the NYC Act's rescission process. ${ }^{247} \mathrm{~A}$ preliminary listing might be employed under the same circumstances as the U.K. Planning Act's temporary notice-namely, when an unlisted building is in danger of demolition or alteration. ${ }^{248}$ The standards for preliminary listing would be less stringent than the standards for a traditional designation. After a term of years, the building would be up for either permanent listing or rescission, whether or not the public has suggested either. The goal of a preliminary listing system in Abu Dhabi would be to protect modern buildings that have the potential to become landmarks, but without freezing them in time for perpetuity in case their significance wanes over the years.

\section{Summary of Proposed Application of the NYC Act and the UK Planning Act to Abu Dhabi}

In summation, Abu Dhabi's policy goals should reflect a desire to preserve architecture for future generations and to manage architectural heritage in a way that is mindful of the city's progress. Abu Dhabi should create a commission to oversee landmark designation. That commission should consist of people with diverse backgrounds who can properly represent the varied viewpoints on preservation and modernization. The commission should allow input from the public regarding which buildings should be landmarked. The final decision-maker should be required to take into account the commission's recommendation and the recommendation of any other parties with special interest in the building. Abu Dhabi should develop guidelines that outline the criteria for granting landmark status. These criteria should include special architectural or historic interest, but should include a very young age requirement or none at all. Abu Dhabi should use landmark status as a shield against some alterations and demolitions, but it should permit them in some circumstances. Landmark

245. This idea is inspired by Gregory Ashe's proposed "Architectural Landmark Designation." See generally Ashe, supra note 217.

246. See U.K. Planning Act § 3(1).

247. See N.Y.C., N.Y., Admin Code § 25-303(h) (2013).

248. See supra note 178 and accompanying text. 
status should require proper upkeep, but the government should try to provide grants to landmark owners in need. Abu Dhabi should also provide for transferable rights for developers. Abu Dhabi should provide for temporary listing of a building in urgent situations. Abu Dhabi should have an accessible process for rescinding landmark status, including a preliminary listing and reassessment option.

\section{B. How These Suggestions Would Further ADACH's Five Goals}

Recall that ADACH has outlined the five goals of its Modern Heritage Preservation Initiative. ${ }^{249}$ The goals include cultural, social, economic, political, and legal considerations. ${ }^{250}$

The cultural goal is to include modern architecture in people's definition of heritage. ${ }^{251}$ Giving certain modern architecture landmark status, and providing accessible information about those landmarks will gradually introduce to the public the idea that modern buildings are an important part of Abu Dhabi's culture.

The social goal is to make modern heritage buildings desirable. ${ }^{252}$ Status as a protected landmark is sort of a stamp of approval on a building's importance and value. It means that a building is special enough that the government wants to preserve it. Landmark status can make a building and its surrounding area more valuable, which in turn can make it more desirable. $^{253}$

The economic goal is to create incentives for building owners. ${ }^{254}$ Offering transferable development rights would help calm concerns that preservation laws will stifle new construction and expansion. A company might even seek out landmark status for its building in order to gain the opportunity for larger expansions elsewhere (not to mention the landmark status would make the building more prestigious and valuable). Further, a grant program might keep building owners from resisting landmark designation because of their fear of costly maintenance.

The political goal is to help government agencies work together to plan development and enforce owners' duties. ${ }^{255}$ Under the suggestions made in this Note, Abu Dhabi would create a new entity in the landmarks commission, whose members would likely be selected by a government official. Developing policies and regulations governing preservation will require the cooperation of the commission, $\mathrm{ADACH}$, city planners, and lawmakers.

\footnotetext{
249. See supra Part II.C.

250. See supra text accompanying notes $41,43-46$.

251. See Chabbi \& Mahdy, supra note 2, at 82 .

252. Chabbi \& Mahdy, supra note 2, at 82 .

253. Chabbi \& Mahdy, supra note 2, at 82 .

254. Chabbi \& Mahdy, supra note 2, at 82.

255. Chabbi \& Mahdy, supra note 2, at 82.
} 
The legal goal is to create regulations for protecting buildings and approving alterations. ${ }^{256}$ Per the suggestions in the preceding section of this Note, Abu Dhabi can draw guidance from the established regulations in New York City and London. By merging and adapting many of the elements of those cities' laws, Abu Dhabi can create effective mechanisms to select buildings worthy of landmark status and protect them from inappropriate alterations and demolitions.

Thus, by adopting the suggestions in this Note, ADACH can further all five goals of its initiative.

\section{CONCLUSION}

The city of Abu Dhabi makes for an interesting case study of how best to preserve what is not yet "history." Because Abu Dhabi was essentially reborn in the mid-twentieth century, it has few buildings that would fit the traditional definition of a landmark. Despite the "newer is better" mentality of some developers in Abu Dhabi, preservationists still recognize that modern architecture is part of the built environment, which deserves protection.

The built environment of any community holds cultural, aesthetic, and economic value for the people of that community. As such, a city or country's laws should demonstrate a public policy in favor of protecting its most important buildings. In New York City, the Landmarks Preservation Act has been in place since 1965. Under the direction of the Landmarks Preservation Commission, thousands of landmarks have been designated. The designation process is long and complex, but the Act provides significant protection against alterations. On the other hand, the city's Zoning Resolution makes up for some of the limitations placed on landmark owners, which is part of the reason the Act survived the Supreme Court's scrutiny.

London's significant architecture has been protected under the Planning (Listed Buildings and Conservation Areas) Act since 1990. With the expertise of English Heritage and its extensive published guidelines for selection, the Secretary of State has listed hundreds of buildings in London. As in New York City, landmarks are protected from alteration unless consent is granted.

By drawing from these two preservation regimes, ADACH can develop the necessary legal mechanisms to begin preserving Abu Dhabi's modern buildings. It will be important, however, to consider the unique nature of Abu Dhabi's history and to adapt the regulations of these much older cities into something that will be appropriate and effective. In doing so, ADACH should be able to successfully address the five goals of its 2011 initiative.

\footnotetext{
256. Chabbi \& Mahdy, supra note 2, at 82 .
} 